\title{
Behavior of Schistosoma mansoni-induced histopathological lesions in Biomphalaria glabrata submitted to ionizing radiation
}

\author{
Comportamento das lesões histopatológicas induzidas pelo Schistosoma mansoni \\ em Biomphalaria glabrata após radiação ionizante
}

\author{
Carine M. Azevedo ${ }^{1}$, Claudia Cunha Borges ${ }^{2}$ and Zilton A. Andrade ${ }^{3}$
}

\begin{abstract}
Present report demonstrates that repeated radiation of Schistosoma mansoni-infected Biomphalaria glabrata, totaling 15,000 rads, caused a sudden, albeit transient, suppression of cercarial shedding. Initially, sporocysts practically disappeared from the snail tissues. The more resistant developing cercariae presented nuclear clumping and vacuolation, before undergoing lysis. No host tissue reaction was evident at any time. Thirty-four days after the last irradiation, the snails resumed cercarial elimination. By that time numerous sporocysts and developing cercariae were detected, disseminated throughout snail tissues in a pattern similar to that of a highly malignant neoplasm, with no signs of host cellular reactions, which on the other hand were present in non-irradiated infected controls. The region of the ovo-testis was apparently destroyed after radiation, but returned to its normal appearance around 40 days after the last radiation. Ionizing radiation affected both host and parasite in S. mansoni-infected Biomphalaria glabrata, but the resulting impressive changes were soon reversed.
\end{abstract}

Key-words: Schistosoma mansoni. Biomphalaria glabrata. Ionizing radiation.

\section{RESUM0}

0 presente trabalho demonstra que a irradiação repetida, num total de 15.000 rads, resulta numa rápida supressão da eliminação das cercarias em caramujos infectados pelo Schistosoma mansoni. Inicialmente os esporocistos desaparecem dos tecidos. As formas evolutivas das cercarias são mais resistentes e apresentam vacuolização citoplasmática e condensação nuclear antes de desaparecerem. Năo foram observadas reações nos tecidos do hospedeiro. Trinta e quatro dias após a última irradiação, os caramujos voltam a eliminar cercárias. Numerosos esporocistos e cercárias em desenvolvimento aparecem infiltrando difusamente os tecidos à maneira de uma neoplasia maligna, sem sinais de oposição da parte do hospedeiro, a qual era visível nos controles infectados e não irradiados. A região do ovo-testis apareceu destruída após a radiação, mas retornou à sua aparência normal em torno de 40 dias mais tarde. A radiação ionizante afeta tanto o hospedeiro como as formas em desenvolvimento do parasito, mas estas alterações impressionantes são logo reversíveis.

Palavras-chaves: Schistosoma mansoni. Biomphalaria glabrata. Radiação ionizante.

A previous study from this Laboratory had noted that a strain of Biomphalaria glabrata, highly susceptible to Schistosoma mansoni, were seen to shed less and less cercariae along the time of infection ${ }^{3}$. It was also observed that such changing pattern of cercarial shedding presented a good histological correlation. An initial picture of nonreaction ( tolerance) gradually turned into one of hemocyte proliferation, with formation of focal encapsulating lesions around disintegrating sporocysts and cercariae. These findings suggested the existence of a primitive form of acquired immunity in invertebrates. In order to explore further along these lines, a plan to eradicate a previous schistosomal snail infection with irradiation was initiated.

1. Programa Institucional de Bolsas de Iniciação Científica do Conselho Nacional de Pesquisa da Universidade Federal da Bahia, Salvador, BA. 2. Course of Experimental Pathology, Fiocruz/UFBA. 3. Head, Laboratory of Experimental Pathology. Centro de Pesquisas Gonçalo Moniz da Fundação Oswaldo Cruz, Salvador, BA, Brasil Supported by PAPES III ( FIOCRUZ).

Address to: Dr. Zilton A. Andrade. Laboratory of Experimental Pathology/CPqGM/FIOCRUZ. R. Valdemar Falcão 121, Brotas 41295-001 Salvador, BA, Brasil. Recebido para publicação em 25/10/2003

Aceito em 13/4/2004 
Ionizing radiation of snails has been used for various purposes. Michelson and Dubois ${ }^{8}$ applied low-dose radiation $(60 \mathrm{Co})$ to Biomphalaria glabrata and observed an enhancement of resistance to Schistosoma mansoni infection. Other workers have used irradiated miracidia to infect B. glabrata in an attempt to increase resistance against S. mansoni, with apparently good results ${ }^{5}{ }^{9}$. When all irradiated miracidia died within snail tissues, a strong resistance was observed to a further challenge with normal miracidia.

At first, our attempt at irradiating S. mansoni-infected snails aimed to eradicate the developing parasite in order to observe whether such a procedure would stimulate the development of an equivalent of acquired immunity in the invertebrate. This proved to be impractical due to the unexpected behavior of the larval forms of S. mansoni within the snail tissues following irradiation. However, the data obtained by a subsequent histological study revealed several points of interest on the differential susceptibility of the developing forms of the parasite, and also of the host tissues with their differential degenerative and regenerative capacities toward radiation damage. Thus, the second part of the research was to observe the behavior of the snail tissue changes upon reinfection. Since no similar data were found in the literature reviewed, the publication of these results appeared to be of interest.

\section{MATERIAL AND METHODS}

Laboratory raised adult Biomphalaria glabrata from Feira de Santana strain ${ }^{1}$ were infected with $20 \mathrm{~S}$. mansoni miracidia (FS strain) freshly isolated from eggs extracted from the liver and intestines of experimentally infected mice. When the snails started eliminating cercariae they were irradiated with cesium 137 (IBL 937CIrradiator, type H, Cis Bio International, Gif-sur-Yvette, France) with the objective of eradicating the infection. At first, 24 snails were irradiated with two doses of 4,000 rads, delivered with an interval of one week. A similar second trial was made with another 30 infected snails. These were submitted to 4 doses of 2,000 rads each atweekly intervals, with results comparable to those of the previous group. Then, radiation doses were changed to 4 sessions of 3,000 rads each ( 24 infected snails) at weekly intervals and 3 doses of 5,000 rads each ( 36 infected snails), at two-day intervals. In these last two groups cercarial elimination stopped and 30 to 48 days later the snails were killed for microscopic examination. Although they were not yet eliminating cercariae, an extensive dissemination of the multiplying forms of $S$. mansoni in the tissues was observed in these animals, as detailed below.

Each irradiated group was always matched with a control group of about 20 non-irradiated and infected snails. They regularly eliminated cercariae throughout the time of the experiment. Cercarial elimination was monitored by examination of individual snails placed into $100 \mathrm{ml}$ beakers containing $10 \mathrm{ml}$ of de-chlorinated tap water. Each specimen was exposed to bright light during an hour, for cercarial shedding and counting. The snails were examined at various days post-infection.
For histological examination the snails were submitted to anesthesia with menthol crystals for 4 hours before being removed from the shells. The entire snail was placed in Bouin's fluid during 5 hours for fixation and then transferred to $70 \%$ alcohol. Further procedures included dehydration in 100\% alcohol, clearing in xylol and embedding in paraffin. Sections were routinely stained with hematoxylin and eosin.

\section{RESULTS}

Irradiated infected snails became negative for cercarial elimination one week following the second radiation, regardless of the doses used, but 34 days later they were seen to resume elimination. The number of eliminated cercariae varied from 3 to 118 immediately before radiation, and dropped to 1 ( minimum) and 59 (maximum) when examined one week after the first radiation. Histological examination of the infected snails, both controls and irradiated, during the period of cercarial elimination, revealed the presence of numerous sporocysts and several stages of developing cercariae located in several organs and tissues, especially in ovo-testis, digestive glands and the tubular and secular portions of the kidney. (Figures $1 \mathrm{~A}$ and $\mathrm{B}$ ). The presence of hemocytes ( amebocytes) was a constant feature. They formed mild to moderate accumulations around the parasitic structures, sometimes assuming a concentric distribution around them and, rarely, differentiating into granuloma-like structures (encapsulating complexes).

The snails examined one to two weeks after the end of the irradiation sessions, at a time when cercarial elimination had completely stopped, revealed a different histological picture. Hemocytes were rarely found, usually appearing isolated in only a few places. No discernable sporocysts were detected after a thorough search in various microscopic sections. Developing forms of cercariae, especially the more differentiated ones, presented fragmentation, condensation of nuclear material and the presence of empty vacuoles of different sizes. (Figure 1C and D). Clumps of eosinophilic debris, probably representing necrotic parasites, were present in several places. There was a mild to moderate degree of edema in several tissues. The ova and spermatozoids completely disappeared from the ovo-testis, which structure assumed a mosaic aspectformed by empty spaces delimited by slender and wavy membranes. The spaces delimited by membranes sometimes contained remnants of cercariae.

When the histological examination was performed in irradiated snails that resumed cercarial elimination, there appeared numerous sporocysts throughout the tissues without any signs of tissue reaction. Also, many cercariae in several stages of development were present. Within the ovo-testis parasitic multiplication and infiltration appeared more evident than the signs of tissue regeneration. The latter were represented by clusters of ova and only a few spermatozoids (Figure 1D and E). Other snail tissues did not exhibit the radiation-related degenerative and regenerative features observed in the ovo-testis. Snails irradiated four times with 3,000 rads every 7th day or three times with 5,000 rads at two-day intervals stopped 


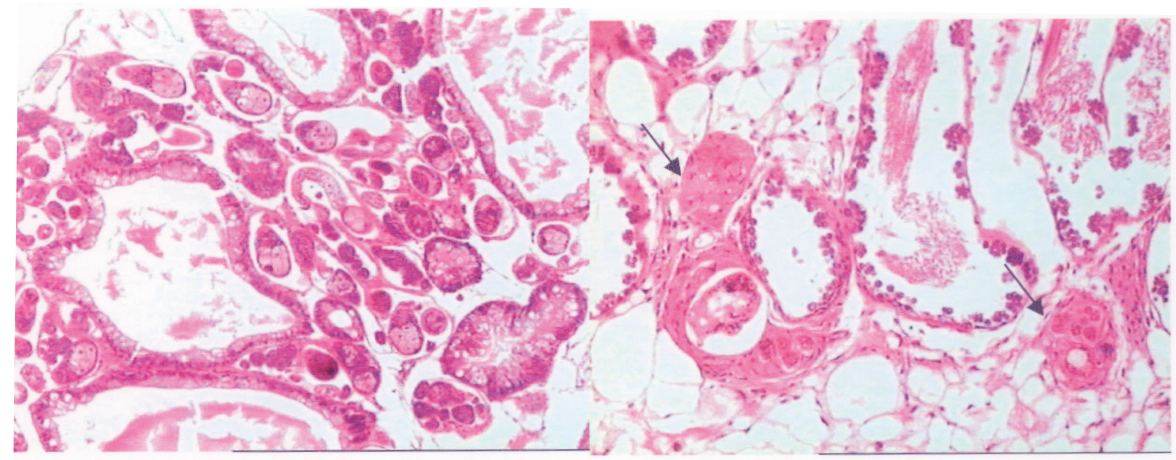

A

B

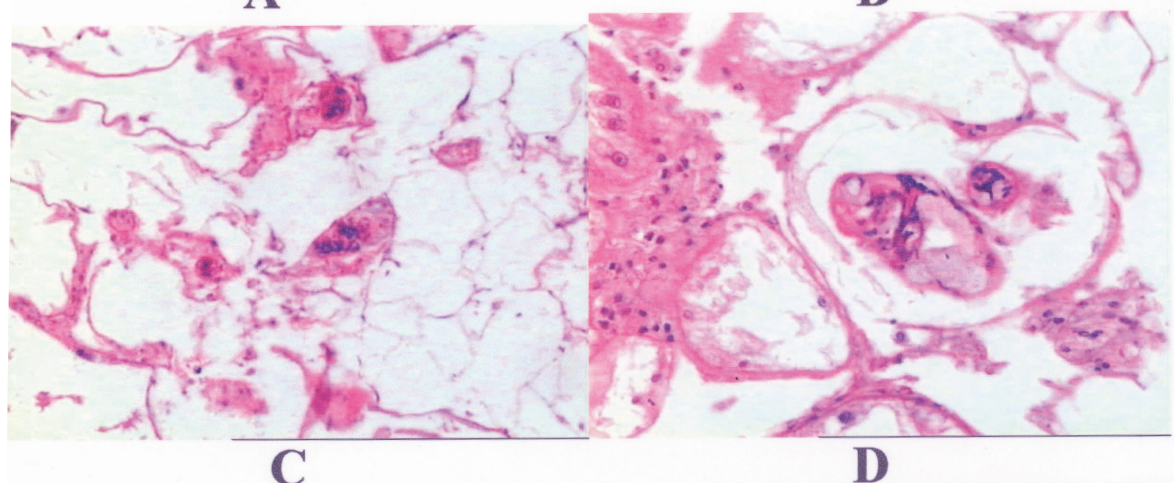

C

D

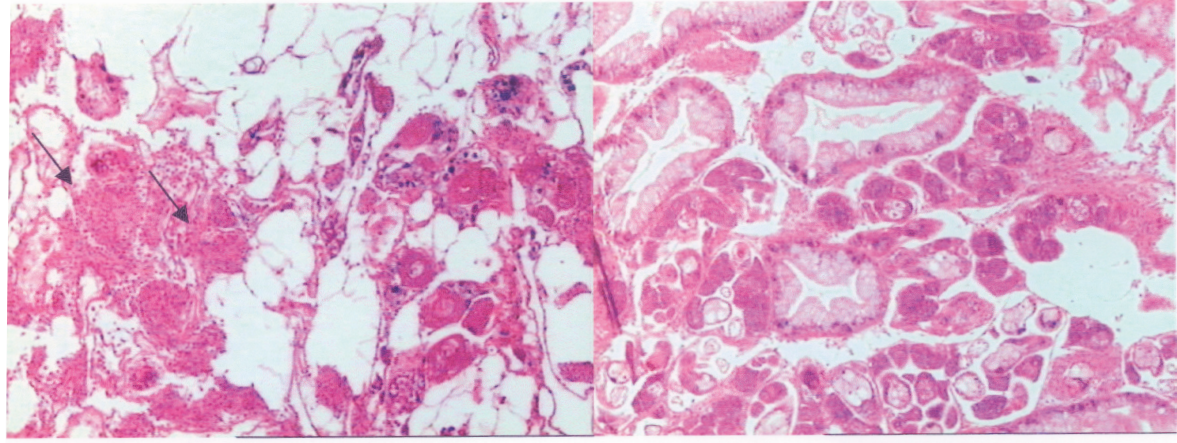

$\mathbf{E}$

F

Figure 1 - A and B - Normal infected snail control; A - Presence of numerous sporocysts and developing cercariae within the edematous interstitial tissue of the digestive glands. B - Tissue reaction is represented by focal accumulation of amebocytes around almost mature cercariae in the ovo-testis (arrow). C and D - Irradiation damage to both cercaria and ovo-testis, as observed two weeks after sessions of gamma radiation. Cercariae presenting nuclear clumping and cytoplasmic vacuoles are seen within the empty spaces created by the disappearance of the cellular elements of the snail ovo-testis. $\mathbf{E}$ and $\mathbf{F}$ - Infected snails examined 48 days after the last session of radiation. The ovo-testis presents both ovum (arrows) and proliferating parasite forms (E). Numerous sporocysts and cercariae are present in the digestive gland interstitial tissue (F). All photographs taken from hematoxylin and eosin stained slides. Magnification: X100, except D (X200).

eliminating cercariae. After 30 to 48 days they were killed and microscopically examined. A histological picture was observed entirely similar to that of the snails that were eliminating cercariae after a temporary post-radiation suppression, which indicated that they were about to resume cercarial elimination.

Thus, both the snails and the multiplying parasitic forms presented a high degree of resistance to ionizing radiation. In a separate experiment we submitted 12 adult non-infected B. glabrata to radiation and kept 14 as non-irradiated controls. After 48 days, 3 of the irradiated snails and two of the controls had died, showing that irradiation was indeed well tolerated by normal B. glabrata. Mortality of infected snails was high, regardless of radiation. It was difficult to obtain precise comparative figures because many snails were sacrificed during the experiment for microscopic examination.

\section{DISCUSSION}

The behavior of the developing stages of S. mansoni within its intermediate snail host following irradiation was strikingly reminiscent of that of a highly malignant neoplasm when irradiated. At first the proliferating cells were almost completely destroyed, but this was soon followed by a 
recrudescence of cellular multiplication, that diffuselyinvaded the host tissues. Also in keeping with what is generally known about the pathology of irradiation, the less differentiated and rapidly multiplying forms, the sporocysts, were the most susceptible elements. As expected, the ovo-testis was the mostsusceptible host tissue to be affected by ionizing radiation ${ }^{4}$. Its return to normal after radiation damage occurred at about the same time the invading parasites were re-emerging. The other snail tissues appeared more resistant, since they exhibited no evident destructive lesions that could be attributed to radiation.

The situation of the defense cells, collectively designated as hemocytes, is a more complex matter. Hemocytes are considered highlyresistant to radiation ${ }^{2}$. The presentstudy revealed an apparent decrease in both hemocyte number and function as a result of radiation. In non-irradiated infected snails these cells were easily found, sometimes accumulated in small focal areas, and eventually forming the so-called encapsulating complexes around destroyed parasites. Although they did not altogether disappear during and after radiation, they became fewer and isolated, and did not form encapsulating complexes around radiation-destroyed cercariae. Also, when parasite multiplication was fully resumed, no evident histological signs of hemocyte proliferation were observed. However, it is possible that hemocyte reactivity would require more time to be fully established, and probably would have become evident had the time of observation been further extended after the post-radiation resumption of cercarial elimination. As demonstrated by the observations of Lemos and Andrade ${ }^{3}$ the apparent tolerant behavior of hemocytes at initial infection, progressively turned into one of proliferation and differentiation of granuloma-like structures with time.

\section{REFERENCES}

1. Andrade ZA, Sadigursky M. Um estudo comparativo das cepas Feira de Santana (Bahia) e Porto Rico do Schistosoma mansoni na infecção experimental do camundongo. Memórias do Instituto Oswaldo Cruz 80: 37-40, 1985.

2. Bezerra FSM, Machado JAN, Souza RLM, Chaves MM, Correa RF, Coelho PMZ. Effect of gamma radiation on the activity of hemocytes and on the course of Schistosoma mansoni infection in resistant Biomphalaria tenagophila snails. Memórias do Instituto Oswaldo Cruz 98: 73-75, 2003

3. Lemos QT, Andrade ZA. Sequential histological changes in Biomphalaria glabrata during the course of Schistosoma mansoni infection. Memórias do Instituto Oswaldo Cruz 96: 719-721, 2001.

4. Liard F, Chiriboga J, Pellegrino J, Colon JI, Silva RM. Effect of radiation on the reproductive potential of Biomphalaria glabrata. Revista Brasileira de Pesquisa Médica e Biológica 1: 157-162, 1968.

5. Lie KJ, Heyneman D. Studies on resistance in snails. 3. Tissue reactions to Echinostoma lindoiense sporocytes in sensitized and resensitized Biomphalaria glabrata. Journal of Parasitology 62: 51-58, 1976.

6. Lie KJ, Heyneman D, Richards CS. Biomphalaria glabrata. Temporary reduction of snail's natural resistance to Schistosoma mansoni by irradiated Echinostoma paraensi miracidia. Experimental Parasitology 43: 54-62, 1977.

7. Lie KJ, Jeong KH, Heyneman D. Acquired resistance in snails. Induction of resistance to Schistosoma mansoni in Biomphalaria glabrata. International Journal of Parasitology 13: 301-304, 1983.

8. Michelson EH, Dubois L. Resistance to schistosome infection in Biomphalaria glabrata induced by gamma radiation. Journal of Invertebrate Patholology 38: 39-44, 1981.

9. Sullivan JT, Richards CS, Joe LK, Heyneman D. Ribeiroia marini irradiated miracidia and induction of acquired resistance in Biomphalaria glabrata. Experimental Parasitology 53: 17-25, 1982. 